\title{
A SURVEY OF NON-TRAUMATIC PARAPLEGIA
}

\author{
By NoRval Watson \\ Lodge Moor Hospital, Sheffield
}

THE policy of admission to the Spinal Injuries Unit at Lodge Moor Hospital, Sheffield, has always been to accept new spinal injuries immediately, irrespective of age or severity of injury, as our first priority. We have always been prepared to accept cases of paraplegia and quadriplegia due to non-traumatic diseases as soon as they have completed their investigation and treatment at a general hospital and are deemed fit to start their rehabilitation programme. On a few occasions during the last 30 years this has meant a small short waiting list, but commonly these cases are admitted within a few weeks of the development of their illness. We make a point of assessing their suitability while they are still in their general hospital to avoid the admission of unsuitable cases and to assess any degree of priority.

The treatment of these non-traumatic paraplegias has been most rewarding as many of them have incomplete lesions and have achieved a very high standard of independence. Their management on the whole has been similar to that of traumatic cord injuries, with the exception that they are usually able to be mobilised into a wheelchair soon after admission to the Unit, as they do not require the lengthy period of bed rest of the traumatic group.

Most come for a complete rehabilitation programme but others are admitted for particular problems of spasticity, bladder training or other aspects of their disability. They appear to benefit from the enthusiastic environment of an active spinal injuries centre and invariably they remain on our register and enjoy the same comprehensive after-care of the traumatic injury.

A survey has been made of the numbers of patients with non-traumatic paraplegia who have been admitted to the Unit during the 30 years 1950-79 inclusive. Out of a total of over 2000 cases, I4I8 were traumatic and 655 nontraumatic, a ratio of just over 30 per cent. This ratio, however, varied from year to year between extremes of I5 per cent in earlier years and 45 per cent in recent years. This higher ratio in recent years reflects the increased number of patients with neurological disorders being referred for urinary dynamic studies.

Up till 1962 only males were admitted to the Unit and the incidence of non-traumatic paraplegia was 29 per cent. Female patients were admitted after 1962 when the size of the Unit was increased from 42 to 64 beds. During the years $1962-79$ the ratio of traumatic cases between the sexes was one female to 4.5 males and we were never able to justify a full ward of 22 beds for female traumatic cases. But the introduction of female cases produced almost equal numbers of four females to five males in the non-traumatic group so that we were able to utilise our female ward adequately. More recently our policy of taking over the management of spina bifida cases at the age of 16 years from paediatric hospitals has also increased the utilisation of female beds.

With regard to the aetiology of the non-traumatic group, the various diagnoses are listed in the table and it will be seen that disseminated sclerosis, tumours of 
TABLE I

\begin{tabular}{|c|c|c|c|c|c|c|}
\hline \multirow{3}{*}{ Years } & \multicolumn{6}{|c|}{ Incidence } \\
\hline & \multicolumn{3}{|c|}{ Non-trauma } & \multicolumn{3}{|c|}{ Trauma } \\
\hline & $\mathbf{M}$ & $\mathrm{F}$ & Total & $\mathbf{M}$ & $\mathrm{F}$ & Total \\
\hline $\begin{array}{l}\text { I950-62 } \\
\text { Men only }\end{array}$ & I 72 & - & 172 & 438 & - & $43^{8}$ \\
\hline \multirow[t]{2}{*}{ I963-79 } & 263 & 219 & 482 & 804 & $\mathrm{I} 76$ & 980 \\
\hline & & & 654 & & & I4I 8 \\
\hline
\end{tabular}

various types and vascular insufficiency were the three commonest groups of diseases responsible for the paraplegia. Disc protrusions and infections of various types, mostly pyogenic, tuberculous and viral were the next commonest groups.

Our normal policy is to admit non-traumatic paraplegia which is nonprogressive and which is capable of worthwhile rehabilitation for a period of years. Most of the demyelinating group, which formed the largest single group, were not admitted for general nursing care, but for management of specific problems of the bladder or excessive spasticity requiring treatment by peripheral corrective surgical and central chemical procedures to make their management easier at home.

TABLE II

\begin{tabular}{lrrr}
\hline & \multicolumn{3}{c}{ Aetiology } \\
\cline { 2 - 4 } \multicolumn{1}{c}{ Disease } & M & F & Total \\
\hline D.S. & IO7 & 78 & I85 \\
Tumour & 65 & 36 & IOI \\
Vascular lesions & 42 & 26 & 68 \\
Discs & 39 & II & 50 \\
Trans. myelitis & 24 & I5 & 39 \\
Tuberculosis & I8 & 8 & 26 \\
Abscess & I8 & 6 & 24 \\
Myelopathy & I3 & 3 & I6 \\
Arachnoiditis & II & 5 & I6 \\
Stroke & IO & 5 & 15 \\
Spondylosis & I I & 3 & I4 \\
Polio & IO & I & I I \\
Pagets & 8 & 3 & I I \\
Myeloma & 9 & I & IO \\
Myopathy & 7 & 3 & I0 \\
Iatrogenic & 6 & 3 & 9 \\
Polyneuritis & 3 & 5 & 8 \\
Hysteria & 7 & 0 & 7 \\
Syringomyelia & 6 & 0 & 6 \\
Others & 22 & I8 & 40 \\
& & & \\
& 436 & 219 & 655 \\
\hline
\end{tabular}


With regard to the second largest group of tumours, it was not our policy to admit secondary malignant tumour cases but to assist those with intrinsic and extrinsic spinal tumours which are usually only locally invasive, and who had a fair prognosis for useful rehabilitation.

A major problem in diagnosis were the patients who became paraplegic over a variable period of time ranging from a few minutes to several hours, and who were admitted to neurosurgical departments for investigation. A fair number were proved to have angiomatous malformation and most of these had surgical treatment. But a larger number were found to have no abnormality on myelography and as neurosurgical treatment was not indicated the diagnosis could not be accurately made. It is my opinion that a reasonable diagnosis could be made from the history of the episode. Where a patient has a sudden illness, with a prodromal period of pain for a short period, followed by the rapid onset of paraplegia, the pain subsiding as the paraplegia develops, I would consider this as a vascular infarction. In many of these cases only that part of the cord supplied by the anterior spinal artery is involved, confirming the vascular aetiology.

Other cases, which developed paraplegia more slowly over a period of days and usually preceded by a feverish illness, could accurately be labelled as transverse myelitis or myelopathy. But there will always be a number of cases of paraplegia in which the mode of onset and the type of paraplegia does not fall easily into these two categories and the diagnosis will remain doubtful. Fortunately the management of the paraplegia is the same and an accurate diagnosis is unnecessary. With regard to infections, tuberculosis, polio and syphilis are now quite rare compared with the early I950s and there is no doubt also that pyogenic infections of the spine are less common than they were, as we have not admitted any since 1973. The results of acute pyogenic epidural abscess formation are catastrophic and permanent as far as the resulting paraplegia is concerned but the treatment of the subacute granulomatous spinal infection is very rewarding indeed. These patients have a slowly progressive paraplegia with low grade fever and are usually considered by the neurosurgeons to be neoplastic at first until laminectomy and histology reveal a granulomatous lesion. Decompression and antibiotics result in a slow but excellent recovery in the few cases we have had.

The ratio between the sexes proved to be fairly equal in most groups of diseases causing paraplegia but there was a preponderance of males in a few disease groups, disc protrusion, epidural abscess, myeloma, syringomyelia and hysteria.

This last diagnostic group were interesting in that whereas two appeared in 1950 and one in 1963 , the remaining four cases were all admitted to the Unit within a 3-month period in 1978; almost an epidemic.

The iatrogenic group of paraplegics totalled only nine in 30 years, six male and three female. Five of this group developed paraplegia following cardio vascular surgery in the aorta for coarctation, aneurysm or traumatic rupture, and have already been reported to the society by me in 1978 .

One of the remaining four cases developed a partial quadriplegia due to air embolism during chest aspiration of an empyema. He made a fair recovery.

The remaining three cases all developed their paraplegia following epidural block procedures. Two were for routine pelvic operations. One for prostatectomy resulted in a partial paraplegia with little recovery. The other for hysterectomy for cancer of the cervix resulted in a complete paraplegia. The last case was a man with a bad history of cardio-vascular insufficiency who had a lumbar paravertebral sympathetic block with 5 per cent phenol in water for 
intractable claudication of the legs and who was unfit for general surgery. He had a previous block with good relief but on a second attempt he developed paraplegia immediately with a fair degree of recovery during the next 2 months.

\section{SUMMARY}

A survey of cases of non-traumatic acquired paraplegia over a 30-year period revealed an admission rate of about 30 per cent of all new admissions to the Unit. Whereas the usual sex ratio of traumatic cases remained constant at 4.5 males to one female the ratio in non-traumatic paraplegia was almost equal between the sexes, five males to four females, thereby influencing the bed allocations between the sexes.

Iatrogenic cases formed a very small part of the survey.

\section{RÉSUMÉ}

On a levé le plan des cas de l'acquise paraplégie non-traumatique qui ont été admis dans une clinique de lésion vertébrales pendant trente ans. L'inspection a révélé qu'ils se sont monté sà trente pour cent de toutes les nouvelles admissions. La proportion sexuelle des paraplégies traumatiques restait vers quatre males à une femelle environ, mais la proportion entre les cas de paraplegie non-traumatique était presque égale avec cinq males à quatre femelles. Ce fait a touché sur l'allocation des lits entre les deux sexes.

Les cas iatrogéniques ont formé une très petite proportion du série.

\section{ZUSAMMENFASSUNG}

Dreißigjährige Ubersicht von nicht-traumatischen Fällen erwerbener Querschnittslähmung zeigte, daß sie 30\% der Aufnahmen in unserer Klinik ausmachten.

Während die Geschlechtsrate von 4, 5 männlichen zu einem weiblichen Fall unter den traumatischen Fällen konstant blieb, fanden wir beinahe die gleiche Rate in den nichttraumatischen Paraplegikern; nämlich ein Verhältnis von $5 \mathrm{zu} 4$.

Dies hat einen definitiven Einfluß auf die Bettzuteilung in der Abteilung.

Iatrogenische Fälle stellten einen sehr geringen Teil der Serie dar.

\section{REFERENCE}

Watson, N. (1979-80). Paraplegia following cardio vascular surgery. Paraplegia, 17, 294-297. 